DOI 10.1515/linpo-2017-0013

\title{
The phonetic and phonological status of the $r$-phones in Tunisian Arabic
}

\author{
Jamila Oueslati \\ Institute of Linguistics, Adam Mickiewicz University in Poznań \\ jamilao@amu.edu.pl
}

\begin{abstract}
Jamila Oueslati. The phonetic and phonological status of the r-phones in Tunisian Arabic. The Poznan Society for the Advancement of the Arts and Sciences, PL ISSN 0079-4740, pp. 69-85

Some aspects of the participation of the $r$-phones in the phonetic and phonological systems of Tunisian Arabic are discussed against the background of a brief acquaintance with the situation obtaining in Standard Arabic and Classical Arabic. In contemporary Tunisian Arabic six $\boldsymbol{r}$-phones occur and the relations of free variation, complementary distribution and phonological opposition between them are examined. The assimilation of the [r] to [1] is touched upon. The situation of $\boldsymbol{r}$-phones in other Arabic dialects is addressed.
\end{abstract}

Keywords: Tunisian Arabic, the phonetic and phonological systems of Tunisian Arabic, Tunisian dialects

\section{Introductory remarks}

The purpose of this article is to outline the phonetic and phonological status of the $\boldsymbol{r}$-phones in Tunisian Arabic (henceforth $\boldsymbol{T A}$ ). This dialect is one of the communication means used in the ARABIC COMMUNICATIVE COMmUNiTy $(\boldsymbol{A} \boldsymbol{C C})$. Following Ludwik Zabrocki, the communicative community is understood here as a group of people capable of exchanging messages (information) irrespective of the communication means being used (cf. Zabrocki 1970; 1972). The lingual (glossic) situation within the $\boldsymbol{A C C}$ is extremely complex and presenting it transparently is rather challenging. It can even be said that an adequate image of this situation can hardly be projected with exactitude. The $\boldsymbol{A C C}$ is diversified both lingually and lectally, and within it various language subcommunities can be distinguished including the following:

(i) General Arabic language community $(\boldsymbol{G A L C})$, and

(ii) National Arabic language communities $(\boldsymbol{N A L C})$, that is Arabic language subcommunities limited mainly to particular countries, such as: Egyptian, Iraquian, Tunisian, Moroccan, and others. 
The $\boldsymbol{G A L C}$ is served allegedly by General Arabic $(\boldsymbol{G A})$, called Modern Standard Arabic (MSA). However, the status of this language is not clear, so it seems advisable to distinguish two varieties of it, that is:

(i) Pan-Arabic $(\boldsymbol{P A})$, and

(ii) National Pan-Arabic language varieties (NPA) used in particular Arab countries.

Among these latter there can be distinguished, respectively, such quasi-vernacular or rather nationwide varieties as: egyptified, iraqified, tunisified, moroccified, etc.

In addition to these national varieties of $\mathbf{N P A}$, there also developed in Arabic countries, on the basis of local dialects, supradialectal varieties. The unificative politico-sociolinguistic processes brought thus about that in the Tunisian communicative community there operate the following three language varieties, that is:

(i) Pan-Arabic $(\boldsymbol{P A})$,

(ii) Tunisified Pan-Arabic $(\boldsymbol{T P A})$, and

(iii) Pan-Tunisian Arabic (PTA).

A similar triglossic diversity is characteristic of all Arab countries.

An idea believed by many Arabs is that the Pan-Arabic language serves the whole $A C C$, and it is relatively uniform continuing the CLASSICAL ARABIC in a certain sense. However, it does not seem that a variety of Arabic, exhibiting those properties enjoys a real existence. Putting it differently, there is of yet no fully fledged Arab language community using such a uniform Arabic language. Consequently, for the time being, Pan-Arabic can be treated, at best, as a language in highly restricted use, that is, not commonly utilized in practice. Namely, it cannot be denied that there happen to be speakers of Arabic which have mastered Pan-Arabic to a nearly ideal degree. It can be heard in some religious programs (for example in Quran recitations) or in radio or television broadcasting.

The term LITERARY ARABIC $(\boldsymbol{L} \boldsymbol{A})$ can, in turn, be referred both to

(i) the actually used PAN-ARABIC and

(ii) the varieties of NATIONAL PAN-ARABIC

Before proceeding to the discussion proper intended by this article, that is, to the status of $\boldsymbol{r}$-phones in $\boldsymbol{T A}$ some terms necessary for the understanding of the course of subsequent argumentation should be explained.

The term $\boldsymbol{r}$-PHONES, will be in fact restricted to the set of all $\boldsymbol{r}$-like phones occurring in $\boldsymbol{T A}$. The phone (speech sound) as phonetic object, may be understood in various ways. In order to avoid misunderstandings it is advisable to characterize the present approach to the ontological status of this object and the objects primarily related with it, that is to say, sound and phoneme.

For the purpose of defining the phone, the sound conceived of here as a minimal lingual unit will be availed of. Every sound is a concrete individual articulaory-acoustic-auditive object. Being a one-time object, the sound itself irrecoverably disappears in 
the past, after it was produced. Having recorded a sound, only its acoustic or articulatory images are fixed. But the sound and its images are different things.

Having the sound to hand, it is possible to define the PHONE as the set of all sounds, homophonous with a given sound. Consequently, sounds are elements of the corresponding phones. In relation to the sounds, which are concrete individual objects, the phone as a set of sounds is already an abstract object. For transcribing the phones the symbols devised by the IPA will be applied.

Having established the inventory of phones for a given language, the concept of the phoneme can be introduced. In the approach, the PHONEME is defined as a set of phones being in the relation of free variation or complementary distribution and sufficiently similar phonetically but not bound by phonological opposition. Of course, this definition is not completely precise, although satisfactory for the present purposes. The phoneme as a set of phones is already more abstract than the phone.

The above remarks should at least to a decent extent level the ground for bringing the $\boldsymbol{r}$-phones of Arabic and Tunisian Arabic up for discussion.

\section{2. $r$-phones in Literary Arabic}

Traditional Arabic grammar has long directed considerable attention towards the phonetics of the Arabic language, and this was due to the following objectives:

(i) the ascertainment of the correct pronunciation of words for the purposes of the recitations of Quran;

(ii) the determination of the function of phonetics in syntax, morphology, and semantics (cf. Bogusławski 2016: vol. I, 130-135, 347-350, 387-388);

(iii) the identification of phonetic differences in dialects;

(iv) the thorough examination of the functioning of the speech organs for the articulatory description of phones.

What is amazing is that these articulatory descriptions have long been very precise, and in fact do not differ from those of today.

Sibawayhi characterized the $\boldsymbol{r}$-phone as vibrant (harf mukarrar 'repetitious sound') and occlusive $(\check{s}$ adì $d)$. The former term was also later used with the same meaning. Other grammarians also used such terms as: $\operatorname{tad}{ }^{\prime} \bar{l} f$, $\operatorname{tarğ} \bar{l}^{\prime}, \operatorname{irti}^{\prime} \bar{a} d$. All these terms describe a quick vibrating movement of the tip of the tongue touching the upper gum. Contemporary Arab grammarians in principle do not differ from the old ones, treating, however, the $\boldsymbol{r}$-phone not as occlusive $(\check{s} a d \bar{l} d)$ but as a liquid.

Based on contemporary experimental studies in Arabic phonetics (cf. Jameel et al. 2009) the phone [r], in isolation, is described as: trill (vibrant), apical, alveolar and voiced. It is thus produced with vibration of the tip of the tongue against the upper gum, about 6 times. Simultaneously, the back part of the tongue (postdorsum) moves somewhat back in the direction of the back wall of the pharynx and up towards the soft palate (velum). It is articulated with spread lips, that is, the aperture between the lips is extended laterally. The predorsal part of the tongue is slightly caved in. The 
duration time of the articulation of this phone is circa $15-22 \mathrm{msc}$. The geminate $[\mathrm{rr}]$ is twice as long as single [r].

In addition to the trill variant $[\mathrm{r}]$ also the tap variant $[\mathrm{r}]$ should be distinguished, articulated with the shortest contact possible between articulators while the apex strikes only once the upper gum. In contrast to $[\mathrm{r}]$, the postdorsum is slightly lowered and slightly shifted forward. All other features of $[r]$ do not differ from those of [r]. The tap $[r]$ is restricted to certain positions and some speakers. It occurs before $[\mathrm{i}],[\mathrm{a}]$ and $[\mathrm{u}]$ (cf. Jameel et al. 2009: 927ff).

For the sake of summarizing this section let us say that the status of $\boldsymbol{r}$-phones within Arabic phonetic and phonological systems is not completely clear, whence it has been a subject of a rather unending dispute, The inquiry into the phonetic properties of these phones as regards the dimension Plainness (Nonemphaticity)/Emphaticity and the dimension of the degree of Emphaticity (Emphasis) reveals considerable diversity of opinions. In consequence the identification of the distinctions in the set of $r$-phones as: primary emphatic vs secondary emphatic vs emphaticized is controversial. Thus, for example, some scholars classified $\boldsymbol{r}$-phones into mufahhama (emphatic) and muraqqaqa (? nonemphatic), although this latter term is rather ambiguous (cf. Cantineau 1941/1960: 48ff; Younes 1994: 216ff). Also the classification of emphatic consonants into primary and secondary by various linguists may differ and it also affects the classification of $\boldsymbol{r}$-phones. In consequence, such and similar problems make the establishment of the set of $\boldsymbol{r}$-phones in Arabic far from easy and it leads to various solutions (cf. Maamouri 1967/1984: 38ff; Oueslati 2015: 257ff).

\section{The phonetic relations binding the $r$-phones in $T A$}

The set of $\boldsymbol{r}$-phones in $\boldsymbol{T A}$ is comprised of the following five elements:

(i) plain [r];

(ii) emphatic $[\mathrm{r}]$;

(iii) long [r:];

(iv) palatalized [r] ;

(v) tap [r], and

(vi) uvular [R].

In this section the discussion will concern some interphone relations based on the corresponding properties, that is:

(i) articulatory, and

(ii) distributional.

The former properties are derived from the production of phones, and the latter from their occurrence in longer lingual units such as syllables, morphs, words. 


\subsection{Articulatory characteristics}

In regard to their articulation the first five $\boldsymbol{T} \boldsymbol{A}$ phones enumerated above do not diverge much from the respective phones in Arabic, as far as voicedness, vibration, place of articulation, and articulator are concerned. The palatalized $\left[\mathrm{r}^{\mathrm{j}}\right]$ is characterized by the elevation of the antedorsum towards the hard palate (palatum). And this movement of the tongue is similar to that of the vowel [i].

The emphatic [r] of $\boldsymbol{T A}$ diverges in some respects from the emphatic [r] of Arabic, in that the $\boldsymbol{T A}$ phone is somewhat weaker with regard to the degree of emphasis. But similarly to Arabic also in $\boldsymbol{T A}$ the two variants, showing different degrees of emphasis, can be distinguished: a weaker (lenis) and a stronger (fortis). These variants also depend on their phonetic neighborhood. Thus, for example, emphatic fortis occurs mainly in the environment of emphatic consonants or back vowels. However, in order to create a more adequate image of $[\mathrm{r}]$ there should be distinguished within it two subphones, that is, a primary and secondary emphatic. The former is emphatic irrespective of the emphatic consonant environment and occurs only in the following words: [barrị · ' my land', [mra· ] 'woman', [ra:3tl] 'man'. On the contrary, the latter is conditioned by the emphatic consonants and back vowels: [ðṛa:jır] ' co-wives pl', [țoroq] 'ways, methods', [șraf] 'he spend money'.

The phone [r:] is usually interpreted morphologically as geminate [rr]. Its occurrence is restricted to intervocalic and final position. However in this latter position it is semilong. And may be exemplified as follows:

[mur:a:ra] 'gall bladder'; [ber:c:d] 'teapot'; [hor:a:s] 'police officers'

[har·] 'heat'; [gær·] 'to own up'; [ Jar·] 'malignity; hunger'

The $[\mathrm{R}]$ occurs solely in words borrowed from the French language. Over the years, $\boldsymbol{T} \boldsymbol{A}$ absorbed a considerable number of French loanwords. In some of these words the uvular [R] appears. This phone may be treated in $\boldsymbol{T A}$ in a twofold way, that is:

(i) it is preserved as uvular or most frequently

(ii) it is replaced by the apico-alveolar [r].

These two cases may be exemplified as follows:

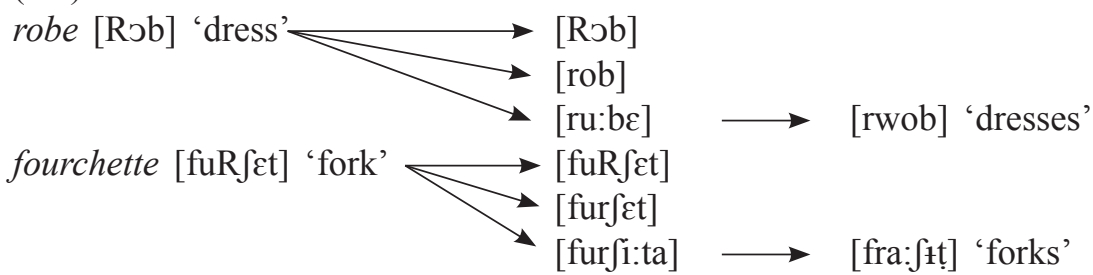

The articulation of [R] is characterized by the approximation with the back of the tongue to the uvula, which results in French either in uvular trill or uvular fricative. These two variants of [R] may also be encountered in Tunisian speakers.

However it should be borne in mind that not all $\boldsymbol{r}$-phones distinguished articulatorily are easily distinguished auditorily. In particular the palatalized [ $\left.\mathrm{r}^{\mathrm{j}}\right]$ and tap $[\mathrm{r}]$ may not be perceived as distinct from the plain [r]. 


\subsection{Phonotactics}

Before proceeding to the phonological relations in which $\boldsymbol{r}$-phones are involved, it would be advisable to inspect all phone environments in which these phones occur. However, subsequently attention will be limited to certain selected problems. Thus, only the environments of the plain [r] will be exemplified in detail, whereas the environments of the other $r$-phones will be only generally touched upon.

The environment of $[\mathrm{r}]$ will be presented in terms of the immediately preceding and the immediately succeeding vowels and consonants.

\subsubsection{The immediately preceding vowels}

Table 3.2.1

\begin{tabular}{|c|c|}
\hline Phone in IPA & Examples \\
\hline [a] & farsa 'mare' \\
\hline [a] & țarțu:r 'non respected, weak (man), henpecked husband' \\
\hline$[\varepsilon]$ & berd'æ 'donkey saddle bag' \\
\hline [æ] & ћærde:n 'finishing (of a grave site)' \\
\hline$[\mathrm{u}]$ & furgæ 'keeping one's distance, separation' \\
\hline [o] & xoroṣ 'hoop earrings' \\
\hline [a:] & fa:ra 'mouse (female)' \\
\hline [a:] & xța:r 'bet' \\
\hline$[\varepsilon:]$ & be:rde 'cold (feminine)' \\
\hline [u:] & fu:r 'oven' \\
\hline [o:] & 'o:ra 'women with lazy eye' \\
\hline
\end{tabular}

\section{2..2 The immediately succeeding vowels}

Table 3.2.2

\begin{tabular}{|c|c|}
\hline Phone in IPA & Examples \\
\hline [a] & brad 'hail' \\
\hline$[\varepsilon]$ & mr\&3 'stress, pressure, tension' \\
\hline$[\mathrm{u}]$ & hru:f 'letters (of alphabet)' \\
\hline [o] & xoro3 'saddle bags' \\
\hline [a:] & xra:fe:t 'folktales; myths; gossips' \\
\hline$[\varepsilon:]$ & mre:jæ 'mirror' \\
\hline [u:] & hru:rijjæ 'hot, spicy' \\
\hline$[0:]$ & ro:h 'soul' \\
\hline
\end{tabular}




\subsubsection{The immediately preceding consonants}

Table 3.2.3

\begin{tabular}{|c|c|}
\hline Phone in IPA & Examples \\
\hline$[\mathrm{b}]$ & bre:rij:d 'tea kettles' \\
\hline$[\mathrm{m}]$ & ћomra 'red spot' \\
\hline$[\mathrm{w}]$ & wraq 'paper; leaves' \\
\hline$[\mathrm{f}]$ & fru:ha:t 'occasions for celebration' \\
\hline$[\theta]$ & Ora·'richness (for example, of land)' \\
\hline [ð] & ðre:ri $\mathrm{i} \cdot$ 'children, kids' \\
\hline [ð] & haðra 'occasion of (Sufi) religious observance' \\
\hline$[\mathrm{t}]$ & metru:s 'hobbled' \\
\hline [d] & dru:s 'lessons' \\
\hline$[\mathrm{n}]$ & nrod 'I vomit' \\
\hline$[\mathrm{t}]$ & mațru:d 'expelled (masculine)' \\
\hline [s] & mosra:na 'intestine' \\
\hline$[\mathrm{z}]$ & zrtd 'petitioning (to a Saint) plural' \\
\hline$[\mathrm{r}]$ & 'orra 'a rude, a savage (woman)' \\
\hline [s] & hașra 'being locked up, closed in' \\
\hline$\left[\int\right]$ & fra:b 'alcohol' \\
\hline$[3]$ & 3ra:n 'frogs' \\
\hline [j] & ћæ:jre 'lazy (feminine)' \\
\hline$[\mathrm{k}]$ & kram 'fig tree' \\
\hline$[\mathrm{g}]$ & gru:n 'horns' \\
\hline$[\mathrm{q}]$ & qra:ja 'attendance (at a school), reading' \\
\hline$[\mathrm{x}]$ & baxra 'woman with bad breath' \\
\hline$[\mathrm{\gamma}]$ & yra:m 'hobbyist, addict (metaphoric)' \\
\hline [ћ] & ћre:m 'item of traditional clothing (of women)' \\
\hline$\left[{ }^{\circ}\right]$ & fa'ra 'a hair' \\
\hline$[\mathrm{h}]$ & mohra 'filly' \\
\hline
\end{tabular}




\subsubsection{The immediately succeeding consonants}

Table 3.2 .4

\begin{tabular}{|c|c|}
\hline Phone in IPA & Examples \\
\hline [b] & rbu:x 'compelling (to dance) rhythm' \\
\hline$[\mathrm{m}]$ & marma. 'goal area' \\
\hline [w] & marwtd 'wooden tool for separating, for example oil and water' \\
\hline [f] & rfu:f 'shelves' \\
\hline$[\theta]$ & 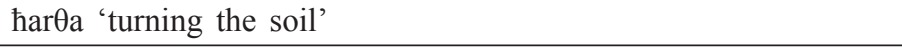 \\
\hline [ð] & morða· 'sick (plural)' \\
\hline$[\mathrm{t}]$ & rte:h 'he rested' \\
\hline [d] & zerde 'petitioning (to a Saint)' \\
\hline$[\mathrm{n}]$ & harna 'stubbornness (of an animal)' \\
\hline [t] & rțal 'pound' \\
\hline$[\mathrm{s}]$ & rsc:le 'letter' \\
\hline$[\mathrm{z}]$ & xærze 'bead' \\
\hline$[\mathrm{r}]$ & șorra/sorra 'package; navel, belly button' \\
\hline [s] & 'arșa 'pole, pillar' \\
\hline [S] & harJa 'coarse, rough' \\
\hline [3] & darza 'step' \\
\hline [j] & merju:1 'sweater' \\
\hline$[\mathrm{k}]$ & rka:k 'unpleasant children, brats' \\
\hline$[\mathrm{g}]$ & marga 'type of goulash; sauce' \\
\hline$[\mathrm{q}]$ & 'arqa:m 'numerals, numbers' \\
\hline$[\mathrm{x}]$ & ferxæ 'pullet' \\
\hline$[\gamma]$ & f\&:ryæ 'empty (feminine)' \\
\hline [ћ] & marћu:1 'expiedition' \\
\hline$\left[{ }^{e}\right]$ & r'ad 'thunder' \\
\hline ['] & mar'u:s 'under (a person in a hierarchy)' \\
\hline$[\mathrm{h}]$ & rhan 'deposit (as on a bottle)' \\
\hline
\end{tabular}

The Table 3.2.3 and 3.2.4 give the information on the consonant clusters of the types $C+r$ and $r+C$, respectively, occurring in $\boldsymbol{T A}$. In order to draw attention to the abundance of the clusters of these types some of them will be enumerated and exemplified. 


\subsubsection{Consonant cluster type $C+r$}

Table. 3.2.5

\begin{tabular}{|c|c|}
\hline $\begin{array}{c}\text { Type consonant cluster } \\
\text { with phone } r\end{array}$ & Examples \\
\hline br & brom 'clay pots' \\
\hline $\mathrm{mr}$ & ћamra 'red' \\
\hline $\mathrm{wr}$ & wrag 'leaves' \\
\hline $\mathrm{fr}$ & fre:di· 'bracelets' \\
\hline$\theta \mathrm{r}$ & 'aOra 'stumbling' \\
\hline$\partial \mathrm{r}$ & ðre:ri· 'children, kids' \\
\hline ðr & ðrab 'he beat (someone)' \\
\hline $\operatorname{tr}$ & 'ætre 'short (of skirt)' \\
\hline $\mathrm{dr}$ & dru:r 'unseen paths' \\
\hline $\mathrm{nr}$ & nru:ћ 'I go' \\
\hline $\operatorname{tr}$ & ma:țra 'rainy' \\
\hline $\mathrm{sr}$ & srad 'very cold (weather)' \\
\hline $\mathrm{zr}$ & xazra 'look, glance; diarrhea' \\
\hline $\mathrm{rr}$ & scrre:j 'early bird' \\
\hline șr & yașra 'being startled' \\
\hline $\mathrm{fr}$ & mafru:b 'drink' \\
\hline $3 r$ & 3ra:d 'locust' \\
\hline jr & 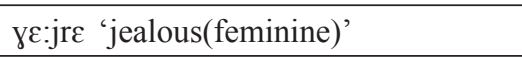 \\
\hline $\mathrm{kr}$ & $\mathrm{kra}^{\mathrm{e}}$ 'leg, foot' \\
\hline gr & gre:d 'ticks' \\
\hline $\mathrm{qr}$ & faqra 'paragraph' \\
\hline $\mathrm{xr}$ & foxra 'bragging' \\
\hline $\mathrm{\gamma r}$ & yra:m 'hobbyist, addict (metaphoric)' \\
\hline$\hbar r$ & se:hre 'witch' \\
\hline er & 're.'nakedness, being in the open' \\
\hline $\mathrm{hr}$ & sahra 'nighttime party' \\
\hline
\end{tabular}




\subsubsection{Consonant cluster type $r+C$}

Table 3.2.6

\begin{tabular}{|c|c|}
\hline $\begin{array}{l}\text { Type consonant cluster } \\
\text { with phone } r\end{array}$ & Examples \\
\hline $\mathrm{rb}$ & rbo' 'a fourth' \\
\hline $\mathrm{rm}$ & garma 'a large piece of fire wood' \\
\hline rw & rwe:ri. 'lungs' \\
\hline rf & htrfe 'craft, trade' \\
\hline $\mathrm{r} \theta$ & 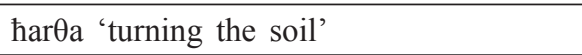 \\
\hline rð & rða. 'he accepted' \\
\hline $\mathrm{rt}$ & rte:h 'he rested' \\
\hline $\mathrm{rd}$ & zerde 'petitioning (to a Saint)' \\
\hline $\mathrm{rn}$ & harna 'stubbornness (of an animal)' \\
\hline $\mathrm{rtt}$ & rțal 'pound' \\
\hline rs & rse:le 'a letter' \\
\hline $\mathrm{rz}$ & rzłm 'load, especially wrapped or in bag' \\
\hline $\mathrm{rr}$ & girre 'long lasting rain; war' \\
\hline rș & garșa 'pinching' \\
\hline $\mathrm{r} \int$ & barfa 'much, many' \\
\hline r3 & 'arza' 'having a limp (feminine)' \\
\hline $\mathrm{rj}$ & rju:g 'saliva' \\
\hline $\mathrm{rk}$ & 'arka 'fighting' \\
\hline $\mathrm{rg}$ & farga 'parting (hair)' \\
\hline rq & firqa 'group of people' \\
\hline $\mathrm{rx}$ & rxa:m 'marble' \\
\hline ry & ryæ. 'loud crying' \\
\hline $\mathrm{rh}$ & rha:m 'vulva and birth canal' \\
\hline $\mathrm{r}^{\mathrm{e}}$ & mar'a'pasture' \\
\hline r' & mar'u:s 'under (a person in a hierarch)' \\
\hline rh & marham 'pomade' \\
\hline
\end{tabular}

All the above tables show a rather high susceptibility of the plain phone [r] to combine with other phones whereby its least restrictive distribution, in comparison to emphatic $[\mathrm{r}]$ and $\left[\mathrm{r}^{\mathrm{j}}\right]$, becomes evident. 


\section{The $r$-phones in the phonological system of $T A$}

The phonological system may be conceived of as an object consisting of:

(i) the set of phones of a given language or dialect and at least

(ii) three relations defined on this set, that is, phonological opposition, free variation, and complementary distribution.

Each of these relations, as a binary, will bind the corresponding phones, and thus it can be treated as a set of the corresponding pairs of phones.

\subsection{Phonological opposition $r$ vs $C$}

Each element of this relation is thus a pair of phones, one member of which is [r] and the other a consonant different from [r]. Such a pair is based in turn upon minimal pairs consisting of two words with distinct meanings. Below, some of the pairs belonging to the phonological opposition $\boldsymbol{r}$ vs $\boldsymbol{C}$ will be enumerated and exemplified accordingly.

$([\mathrm{r}],[\mathrm{b}]): \quad$ ([ru: $\mathrm{h}]$ 'soul', [bu: $\mathrm{h}]$ 'admit it!')

([r], [m]): ([ru:s] 'heads', [mu:s] 'knife; razor')

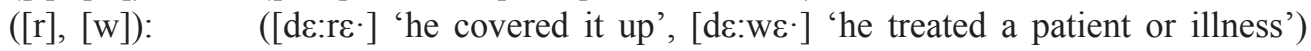

([r], [f]): $\quad$ ([ru:ћ] 'soul', [fu: $\quad$ ] 'smell good (imp)')

$([\mathrm{r}],[\theta]): \quad$ ([rnijjæ] 'feckless', [0nijjæ] 'road to a place')

([r], [ð]): ([jru:b] 'it ferments', [jðu:b] 'it melts')

$([\mathrm{r}],[\mathrm{t}]): \quad([\mathrm{ru}: \mathrm{mi} \cdot]$ 'non-Arab', [tu:mi-] 'twins')

$([\mathrm{r}],[\mathrm{d}]): \quad([\mathrm{ro}: \hbar]$ 'soul', [do:ћ] 'crib')

$([\mathrm{r}],[\mathrm{n}]): \quad$ ([ru:m] 'accept it!', [nu:m] 'sleeping')

$([\mathrm{r}],[\mathrm{t}])$ :

([ra:f] 'he had compassion for', [ta:f]'he rode with the Kaaba, he wandred around')

([r], [s]): ([ru:m] 'accept it!', [su:m] 'price')

([r], [z]): ([ru:z] 'rice', [zu:z] 'twice')

([r], [r:]): ([ha:ra] 'four', [ha:r:a] 'hot, spicy (taste)')

$([\mathrm{r}],[1]):$

([ru:ћ] 'soul', [lu: $\hbar]$ 'wood')

$([\mathrm{r}],[\mathrm{s}]): \quad \quad$ ([rad·] 'he vomited; repeated', [șad·] 'he didn't allow it')

$([\mathrm{r}],[\mathrm{S}]):$

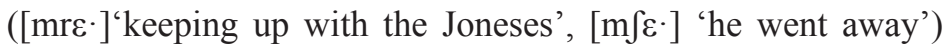

$([\mathrm{r}],[3])$ :

([ru:f] 'be good (to a person)!', [3u:f] 'stomach')

$([\mathrm{r}],[\mathrm{j}])$ :

([ru:mi·] 'non-Arab', [ju:mi·] 'my day')

$([\mathrm{r}],[\mathrm{k}])$ :

([ru:s] 'heads', [ku:s] 'triangle')

$([\mathrm{r}],[\mathrm{g}])$ :

([fu:r] 'oven', [fu:g] 'over, above')

$([\mathrm{r}],[\mathrm{q}]):$

([ra:m] 'he accepted', [qa:m] 'he stood')

$([\mathrm{r}],[\mathrm{x}])$ :

([ru:f] 'be good (to a person)!', [xu:f] 'fear')

$([\mathrm{r}],[\mathrm{\gamma}]):$

$([\mathrm{r}],[\mathrm{h}]):$

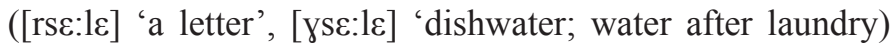

$\left([\mathrm{r}],\left[^{\mathrm{e}}\right]\right)$ :

([ru:m] 'accept it!', [hu:m]'wander!')

([rbe:jæ] 'raising (a child)', ['be:jæ] 'being loaded') 


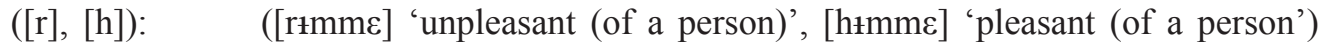

([r], [ð]): $\quad$ ([ram· ' he shook it', [ðam'] 'he embraced')

([r], [t] $] \quad$ ([ru:ba] 'dress', [ț:ba] 'piece of parched earth')

In addition to phonological opposition important also is the so-called phonological co-opposition which is based on quasi-minimal pairs, exemplified below:

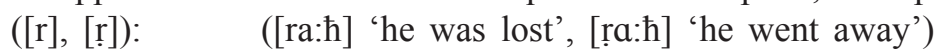

([r], [1]): ([ra:m] 'he accepted', [le:m] 'he had a grudge against someone')

([r], [3]): $\quad$ ([ra:b] 'it fermented', [3z:b] 'he brought it')

$\left([\mathrm{r}],\left[{ }^{\prime}\right]\right): \quad$ ([ra:m] 'he accepted', ['æ:m] 'he swam; he bathed')

In the context of phonological opposition a concept of range operates. Thus, the range of phonological opposition of the phone [r] is the set of all phones with which $[r]$ is in this relation. As can be inferred from the above tables, this range in $\boldsymbol{T A}$ is rather considerable.

\subsection{Free variation and complementary distribution}

The situation of $\boldsymbol{r}$-phones in light of these two relations is rather difficult to describe since these relations do not apply here sensu stricto, in particular this concerns [r] and [r] which, to some extent may be in both free variation and complementary distribution (cf. Oueslati 2015).

\subsubsection{Free variation}

This relation binds phones which are mutually replaceable in some words when such replacements do not cause a change of meaning. Hence a pair of phones belonging to free variation does not belong to phonological opposition.

The free variation is rather rare in $\boldsymbol{T A}$. And it may concern:

(i) plain [r] and emphatic [r] as well as

(ii) plain $[\mathrm{r}]$ and uvular $[\mathrm{R}]$.

\subsubsection{Complementary distribution}

This relation binds those phones which occur in mutually exclusive environments, that is, if one phone appears in a certain environment the other one cannot appear in this environment. Clearly, phones bound by complementary distribution cannot be in phonological opposition. In $\boldsymbol{T A}$ the following pairs of $\boldsymbol{r}$-phones belong to the complementary distribution:

(i) ([r], $[\mathrm{r}]])$, that is, plain $[\mathrm{r}]$ and palatalized [ri $]$, and

(ii) ([r], $[\mathrm{r}]$ ), that is, plain $[\mathrm{r}]$ and emphatic $[\mathrm{r}]$. 
Thus, for example, the palatalized [ri] can occur only before long [i:], and in this position no other $\boldsymbol{r}$-phone can appear. The emphatic [r] , in turn, requires an emphatic environment, that is, either an emphatic consonant or a back vowel.

\section{Towards a phonemization solution}

With the information on the involvement of the $r$-phones in the phonological system, as shown in their participation in the three phonological relations being above considered, the phonemic status of these phones in $\boldsymbol{T A}$ may be approximated. The present phonemization proposals may be formulated in terms of the following hypotheses:

Hy 5.1 The phones [r] and [ $\mathrm{r}^{\mathrm{j}]}$ belong to the same phoneme, that is to say, they can be treated as allophones or variants of the same phoneme.

Hy 5.2 The phones [r] and [r:] belong to different phonemes, that is to say, they are heterophonemic, since there are corresponding minimal pairs (cf. for example, [ha:r:a] 'hot (taste)' [ha:ra] 'four').

Hy 5.3 The relationship of the emphatic [r] to all other $\boldsymbol{r}$-phones is rather unclear. And heterophonemicity or at least quasi heterophonemicity can be considered in this case in view of the phonological co-opposition binding [r] and [r] (cf. for example, [ra:h] 'he was lost' [ra:h] 'he went away'; [bar:i:] 'land' [bar:i:] 'my country').

Obviously, the above hypotheses may turn out as not completely adequate, a point the author is well aware of. More importantly, they reflect only a possible phonemization solution.

\section{A glance at other dialects}

In comparing $\boldsymbol{r}$-phones in Arabic dialects only a few selected problems concerning the phonetic and phonological properties of these phones will be touched upon.

The phones [r] and [r], that is a non-emphatic and an emphatic, occurring in contemporary Arabic dialects do not display significant articulatory differences in comparison to the corresponding phones of the Literary Arabic. It is noticeable however that in the speech of some inhabitants of towns, as for example the Christian minority of Baghdad and many people of the town of Fez in Morocco there may appear a back-tongue velar spirant [y] (cf. Cantineau 1960: 49f; Mitchell 1993: 23f). Mentioned should also be uvular [R] turning up in some French loan words not only in Tunisian, but also in Algerian Arabic and Moroccan Arabic. The uvular [R] is often replaced by [r].

In the Arabic dialects the $\boldsymbol{r}$-phones are in phonetic opposition with each other analogously to Literary Arabic, since they diverge articulatorily from each other. However, the phonological opposition can be observed sporadically in Moroccan and Tunisian. It does not occur however in the eastern dialects (Mašriq) (cf. Cantineau 1960: 49f; Oueslati 2015: 215ff). 
The phonological opposition between $[\mathrm{r}]$ and $[\mathrm{r}]$ in Moroccan can be exemplified as follows:

kbar 'he grew bigger, older' kbor 'bigger, older'; 'gar 'sterility' 'gar 'he hurt (s.o)'.

Generally speaking, the distribution of phones $[\mathrm{r}]$ and $[\mathrm{r}]$ in Arabic dialects operates analogously to Literary Arabic. Nevertheless, certain differences can be noticed particularly in Moroccan Arabic in which the situation is rather complicated. The phones [r] and $[r]$ in this dialect can occur:

(i) in some of the same environments;

(ii) in complementary distribution, that is, in mutually exclusive environments.

Point (i) has been already illustrated in (6.1). And, point (ii) can be exemplified by the following pairs of words:

(6.2) zra 'he ran' zra 'it happened (eg. accident)';

raab 'it fell into ruins' raab 'it curdled';

faarəb 'lip' Jaarəb 'having drunk'.

Thus, (6.2) shows that [r] occurs in the neighborhood of front [a], while [r] occurs in the neighborhood of back $[a]$.

The relationship between $[\mathrm{r}]$ and [r] also offers some rather unexpected developments. Namely, word forms derived from one and the same root in which the original non-emphatic [r] occurs may differ in that some of these forms may have [r] instead of [r]. This is the case, for example, in Egyptian Arabic $(\boldsymbol{E A})$ :

$$
\begin{aligned}
& \text { bard 'cold(ness)' 'abrad 'colder', } \\
& \text { barrad / yibarrad 'to cool sth'. }
\end{aligned}
$$

Observable as well is the tendency to substitute the vowel opposition [a] [a] or [aa] $[\mathrm{aa}]$ for the consonantal opposition $[\mathrm{r}] \sim[\mathrm{r}]$. In consequence, the minimal pairs originally based on the latter opposition are now based on the former, whence the back vowel becomes only a reflex of the original emphatic [r] , as is the case in $\boldsymbol{E} \boldsymbol{A}$ :

(6.4) bard 'cold(ness)' bard 'filling (smoothing with life)'

Similar alternation occurs in $\boldsymbol{E} \boldsymbol{A}$ words creating quasiminimal pairs, e.g.:

(6.5) dars 'lesson' darb 'path';

warra 'he showed' barra 'outside';

raagi' 'returning, having returned' raagil 'man'.

Although emphatic [r] in $\boldsymbol{M} \boldsymbol{A}$ may also occur in the environment of [e] and [i] as, for example:

(6.6) teer 'bird', friib 'drinking'.

Mitchell (1993: 23f) notices a tendency to limit the opposition between [r] and [r] to co-occurence with the vowels $[a(a)] /[a(a)]$ or $[-2-]$.

The $\boldsymbol{r}$-phones in Arabic dialects assimilate to the immediately succeeding [1] from which [11] results. E.g.:

(6.7) In Algerian Arabic ndir lek 'I will make it for you' develops to ndillek; dar lak 'he made it for him' results in dallah (cf. Cantineau 1960: 50f). 


\section{By way of conclusion}

This inquiry into the $\boldsymbol{r}$-phones of $\boldsymbol{T} \boldsymbol{A}$ is not exhaustive. Nevertheless, it is to be hoped that it has contributed at least some modest but relevant information on the phonological and phonemic status of these phones in $\boldsymbol{T A}$. A future discussion may of course verify these statements. Even a study of a limited subset of phones cannot help concerning important phonological problems. However, the $\boldsymbol{r}$-phones of $\boldsymbol{T} \boldsymbol{A}$ make up only a small part of the phonological system operating in this language variety. And it is important to be aware of the mutual relationships obtaining between parts and the corresponding whole. Speaking more precisely, the status of a part is not understandable outside a whole, and conversely, the understanding of the whole at work presupposes the cooperative work of the particular parts.

\section{References}

Al-Ani, Salman. 1992. Readings in Arabic Linguistics. Bloomington: Indiana University Linguistics Club.

Al-Ani, Salman \& El-Dalee, Mohammed. 1983. Tafxīm in Arabic: The acoustic and physiological parameters. Proceedings of The Xth International Meeting of Phonetic Sciences, 385-389. Dordrecht: Foris.

Al-Nassir, Abdulmunim A. 1993. Sibawayh the phonologist. A critical study of the phonetic and phonological theory of Sibawayh as presented in his treatise al Kitab. Library of Arabic Linguistics 10. London, New York: Kegan Paul International.

Anani, Mohammed. 1985. Differences in the distribution between Arabic /1/, /r/ and English /1/, /r/. Papers and Studies in Contrastive Linguistics 20. 129-133.

An̄̄s, Ibrāhīm. 1992. Al-așwāt al-luḡawiyya. Al-Qāhira: Maktabat al-Anglū al-Mișriyya.

An-Nūrī, Mohammed J. 1996. 'Ilm al-așwāt al-'arabiyya. Ğāmi'at al-Quds al-maftūha.

Baccouche, Taïeb \& Mejri, Saleh. 2004 L'atlas linguistique de Tunisie: Les questionnaires. Paris, Tunis: Maisonneuve, Larouse \& Sud Editions.

Bakalla, Mohammed H. 2009. Tafxīm. Encyclopedia of Arabic Language and Linguistics IV, 321-424. Leiden: Brill.

Bańczerowski, Jerzy. 1985. Phonetic relations in the perspective of phonetic dimensions. Studia Lingusitica Diachronica et Synchronica, 25-40. Berlin, New York, Amsterdam: Mouton de Gruyter.

Bańczerowski, Jerzy. 1992. Is generative phonology consequent upon structural phonology? Phonological Investigations. 247-307.

Bańczerowski, Jerzy \& Pogonowski, Jerzy \& Zgółka, Tadeusz. 1982. Wstęp do językoznawstwa. Poznań: Wydawnictwo Naukowe UAM.

Bogusławski, Andrzej \& Drzazgowska, Ewa. 2016. Język w refleksji teoretycznej: Przekroje historyczne. Warszawa: Katedra Lingwistyki Formalnej Uniwersytetu Warszawskiego.

Bonnot, Jean-François. 1977. Recherche expérimentale sur la nature des consonnes emphatique de l'arabe classique. Travaux de l'Institut de Phonétique de Strasbourg 9. 47-88.

Bonnot, Jean-François. 1979. Étude expérimentale de certains aspects de la gémination et de l'emphase en arabe. Travaux de l'Institut de Phonétique de Strasbourg 11. 109-118.

Cantineau, Jean. 1941/1960. Cours de phonétique arabe. Alger. [extended version]. Études de Linguistique Arabe. Paris: C. Klincksieck.

Danecki, Janusz. 1978. Early Arabic phonetical theory. Phonetics of al-Halil ibn Ahmad and Sibawaihi. Rocznik Orientalistyczny 39. 51-56.

Danecki, Janusz. 2000. Współczesny język arabski i jego dialekty. Warszawa: Dialog.

Ferguson, Charles A. 1956. The emphatic $l$ in Arabic. Language 32(2). 446-452.

Ghazeli, Salman. 1981. La coarticulation de 1'emphase en arabe. Arabica: Revue d'Études Arabes 28. 251-277. 
Giannini, Antonella \& Pettorino, Massimo. 1982. The emphatic consonants in Arabic. Speech Laboratory Report 4. Neapoli: Istituto Universitario Orientale.

Istītīh, Samīr. 2003. Al-Așwāt al-luḡawiyya-ru' ya 'uzwiyya wa nuṭqiyya wa fizyā'iyya. 'Ammān: Dār Wā’ il. Iványi, Tamás. 1977. Preliminary distinctive feature analysis of Classical Arabic consonants. Acta Orientalia Scientarium Hungaricae 31. 217-236.

Jameel, Ibtisam H. et al. 2009. Al-Izțirābāt an-nuțqiyya fĩ șawt/r/ fĩ al-'arabiyya: Dirāsa wașfiyya tahlīliyya.

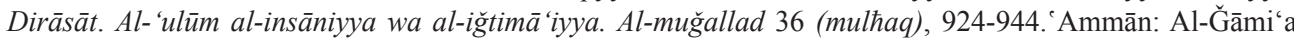
al-Urduniyya.

Kästner, Harmut. 1981. Phonetik und Phonologie des modernen Hocharabisch. Leipzig: VEB Verlag Enzyklopädie.

Khattab, Ghada. 2002. /r/ production in English and Arabic bilingual and monolingual speakers. Leeds Working Papers in Linguistics and Phonetics 9. 91-129.

Ladefoged, Peter. 1975. A course in phonetics. New York, Chicago, San Francisco, Atlanta: Harcourt Brace Jovanovich.

Łobacz, Piotra. 2013. Polskie reranie. Scripta manent - res novae, 245-258. Poznań: Wydawnictwo Naukowe UAM.

Maamouri, Mohamed. 1967/1984. The phonology of Tunisian Arabic. Ithaca, New York: Cornell University. (Doctoral dissertation.)

Mejri, Saleh \& Said, Mosbah \& Sfar, Inès. 2009. Pluringuisme et diglossie en Tunisie. La situation linguistique en Tunisie (Synergies1), 53-74. Tunis: Revue du GERFLINT.

Mitchell, Terence Frederick. 1990. Pronouncing Arabic 1. Oxford: Oxford University Press.

Mitchell, Terence Frederick. 1993. Pronouncing Arabic 2. Oxford: Oxford University Press.

Morsly, Dalíla. 1983. Diversité phonologique du français parlé en Algérie: realization de /r/. Langue française ก 60. Phonologie des usages du français. 65-72.

Mzoughi, Inès. 2015. Intégration des emprunts lexicaux au français en arabe dialectal tunisien. Cergy-Pontoise: Université de Cergy-Pontoise. (Doctoral dissertation.)

Newman, Daniel L. 2002. The phonetic status of Arabic within the world's languages. Antwerp Papers in Linguistics 100. 65-75.

Newman, Daniel L. 2005. Modern phonetic terminology in Arabic: Translation and equivalence. Journal of the Faculty of Arts. 77-86.

Norlin, Kjell. 1987. A phonetic study of emphasis and vowels in Egyptian Arabic. Lund: Bloms Lund.

Odisho, Edward. 1988. Sibawayhi's dichotomy of majhura/mahmusa revisited. al-Arabiyya 21(1-2). 81-91.

Osman, El-Sayed A. 1988. The phonological theory of Sibawaihi: An eighth century Arab grammarian. Washington, D.C.: Georgetown University. (Doctoral dissertation.)

Ouerhani, Bechir. 2009. Interférence entre le dialectal et le littéral en Tunisie: Le cas de la morphologie verbale. La situation linguistique en Tunisie (Synergies1), 75-84. Tunis: Revue du GERFLINT.

Oueslati, Jamila. 2010. Towards a description of the vowel system of a North West Tunisian dialect. Folia Orientalia XLVII (47). 124-139.

Oueslati, Jamila. 2015. The phonetic and phonological systems of the Dzira dialect of Tunisian Arabic. Poznan: Wydawnictwo Rys.

Quitout, Michel. 2002. Parlons l'arabe tunisien: Langue et culture. Paris: L'Harmattan.

Singer, Hans R. 1984. Grammatik der arabischen Mundart der Medina von Tunis. Berlin: Walter de Gruyter.

Skik, Hichem. 1976. Le passage d'une langue à l'autre chez les tunisiens bilingues: Étude socio-linguistique. Revue Tunisienne des Sciences Sociales XIII/4. 140-165.

Skik, Hichem \& Ounali, Mohamed Habib. 1971. Une tentative d'analyse du vocabulaire de l'arabe parlé en Tunisie. Revue Tunisienne des Sciences Sociales VIII/27. 173-177.

Vollers, Karl. 1892. The system of Arabic sounds as based upon Sîbawayh and Ibn Yacish. Transactions of the 9th International Congress of Orientalists II, 130-151. London: International Congress of Orientalists.

Walters, Keith. 1992. A sociolinguistic description of (u:) in Korba Arabic: Defining linguistic variables in contact situations and velic areas. Perspectives on Arabic Linguistics 4. 181-218.

Walters, Keith. 2003. Fergie's prescience: The changing nature of diglossia in Tunisia. International Journal of the Society of Language 3. 85-87.

Watson, Janet C. E. 1999. The directionality of emphasis spread in Arabic. Linguistic Inquiry 30. 289-300.

Watson, Janet C. E. 2002. The phonology and morphology of Arabic. Oxford: Oxford University Press. 
Younes, Munther. 1994. On emphasis and /r/ in Arabic. Perspectives on Arabic Linguistics VI. Papers from the Sixth Symposium on Arabic Linguistics, 215-235. Amsterdam, Philadelphia: John Benjamins.

Zabrocki, Ludwik. 1970. Kommunikative Gemeinschaften und Sprachgemeinschaften. Folia Linguistica 4(1). $2-23$.

Zabrocki, Ludwik. 1972. Z teorii socjolingwistyki. Biuletyn Polskiego Towarzystwa Językoznawczego 30. 17-25. 